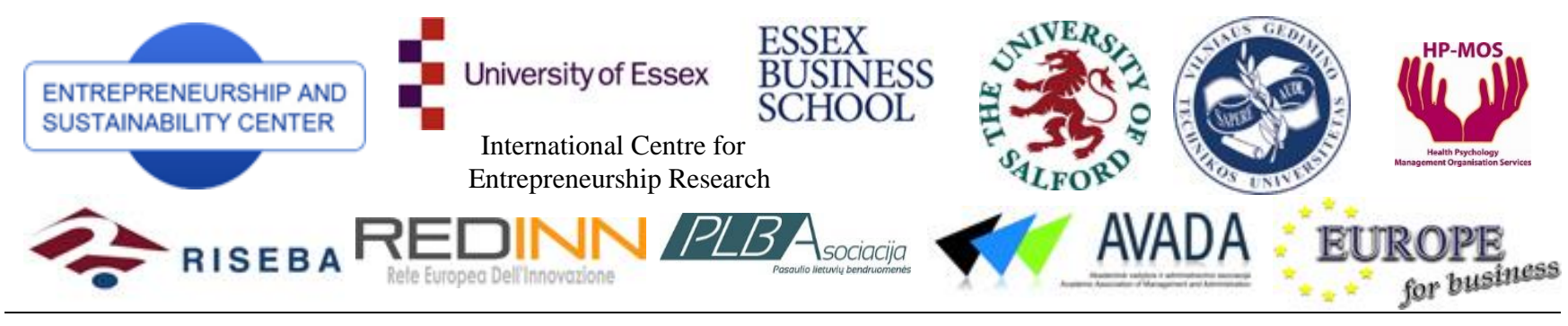

ENTREPRENEURSHIP AND SUSTAINABILITY ISSUES

ISSN 2345-0282 (online) http://jssidoi.org/jesi/

\title{
ECOSYSTEM FOR SUSTAINABLE ENTREPRENEURSHIP: TOWARDS SMART PUBLIC PROCUREMENT REVIEW PROCEDURES
}

\author{
Agnė Tvaronavičienė $\dot{1}^{1}$ Gintarė Žemaitaitienè ${ }^{2}$, Tatjana Bilevičiené \\ 1,2,3 Mykolas Romeris University \\ Ateisties str. 20, \\ 08303 Vilnius, Lithuania \\ E-mails:Ia.tvaronaviciene@mruni.eu; ${ }^{2}$ giparaz@mruni.eu; ${ }^{3}$ tbilev@mruni.eu
}

Received 10 February 2016; accepted 18 May 2016

\begin{abstract}
Although European Union and national regulation have developed public procurement system for many years, different stakeholders (contracting authorities, judiciary, controlling authorities) provide much criticism to these procedures. The article presents results of experts' evaluation of currently applied system and investigates the possibilities for online public procurement review procedure. Lithuania is one of EU leading countries in regard of e-procurement. The results showed that the object of the research is poorly studied, but theoretically formulated problems are relevant in practice. Analysis of problematic aspects might be useful to improve national system of public procurement dispute resolution. As well as might be applied in the practise of other EU countries, seeking to apply social technologies to carry on time and money consuming public procurement procedures. Future researches should be oriented towards analysis of e- public procurement platforms used in the EU member states supplementation with specific modules for purchasing authorities' decisions' review.
\end{abstract}

Keywords: public procurement, online dispute resolution, e-public procurement, social technologies, review procedure.

Reference to this paper should be made as follows: Tvaronavičienè, A.; Žemaitaitienè, G.; Bilevičienè, T. 2016. Ecosystem for sustainable entrepreneurship: towards smart public procurement review procedures; Entrepreneurship and Sustainability Issues 4(1): 39-52.

DOI: http://dx.doi.org/10.9770/jesi.2016.4.1(4)

JEL Classifications: K41, J52, H57

\section{Introduction}

In every state, the proper performance of public procurement is significantly affected by a targeted and coherent public policy in the field and adequacy of managerial and legal measures for its implementation. Today, the current situation is rather paradoxical. The public procurement system that has been developed for many years by European Union and national regulation, in all member states countries still receives much criticism from all 


\section{The International Journal
STAINABILITY ISSUES}

ISSN 2345-0282 (online) http://jssidoi.org/jesi/

2016 Volume 4 Number 1 (September)

parties to these procedures. For instance, contracting authorities escalate the problem of excessive procurement regulation, allegedly excessively detailed regulation precludes the effective purchase process, and a significant administrative burden (Delfi.lt 2008; Maga.lt 2008; Čapas\&Čapas 2013; Oganisjana et al. 2015). Controlling authorities express dissatis faction for obviously inadequate qualification of procurement professionals engaged (Public Procurement Office 2011), and poor procurement planning (Bilkis 2016). Honest businesses dissatisfied with lost potential revenue due to corruption in public procurement (Kyšiai.lt 2009). And finally, society is disappointed by "impunity" for procurement infringements (vz.lt 2014; kaunodiena.lt, 2013). Naturally, such claims are related to a wide range of different and even contrary interest of subjects expressing them. These differences often turn on to serious conflicts, which need to be resolved quickly and effectively. Every EU member country applies certain public procurement disputes resolution system. Review Directive (Directive 2007/66/EC) sets main requirements for it. Still every country also has a wide discretion to design it according to specifics of its legal system. Previous researches (Tvaronaviciene 2014; Pachnou 2003) in this field showed that within EU every country has its own unique system for public procurement review. On one hand, such variety helps countries to retain discretion and to be able to react quickly to the needs of parties to a dispute. Still, on the other hand, it builds certain obstacles for equal competition in the market in regard of steady possibilities to protect violated interests. International entities are facing more difficulties in proper defence of its violated rights to compare with local ones, who know better the national system. Difficult and costly review procedures also are less attractive for small and medium business, which sometimes restrains from taking part in public procurements only because of stereotype that this sector is corrupted and designated for biggest and most powerful entities. Appropriate system of public procurement review is a most effective tool for fully implementation and further supervision of ground principles as transparency, honesty and equal competition. Suppliers participating actively in procurement procedures and reacting to every violation of legal regulation in the field are capable to detect and to counteract every infringement. Such mission will never be possible to various EU and national supervising bodies. Still in order to motivate suppliers to be active in their violated rights defence, the procedure of such dispute resolution should be assessable and easy to use. Having in mind that currently big part of public procurements within EU are already electronical, it raises a question that one of the next steps in improving EU public procurement policy should be transferring EU public procurement review procedures online.

The object of this research is a system of public procurement review. This research aims to identify main problems of currently applied system of public procurement review and to investigate the possibilities for online public procurement review procedure. Lithuania was chosen as one of the leading countries in regard of e-procurement. Such characteristic should be treated as important factor because experts of this country are already enjoying advantages of e-procurements and day after day are taking part in such procedures online.

The results of this research might be useful for improving national system of public procurement dispute resolution, bus as well might be applied in the practise of other EU countries, which also seek to develop and reform analysed sector, by employing social technologies as a tools to carry on time and money consuming procedures. Having in mind the e-invoice initiative (eu2013.lt 2013), which constantly is being implemented in member countries, e-review is an option for EU seeking to unify and fasten public procurement dispute resolution.

\section{The Importance of Appropriate Public Procurement Review Procedure}

Public procurement is a quite complicated system aimed to effective and transparent public expenditure (Girūnas, Mackevičius 2014). Having in mind high purchasing powers of the state governments (Thai 2001), it might be titled as a one of the most important functions of public administration, which have notable impact on development of the each state. Non-proper fulfilling of requirements on public procurement, which are implied by national as well as international legal regulation, always fate difficult consequences. Not only purchasing authorities and suppliers suffers because of infringements, also big damage is done for whole society and especially for its attitude towards public bodies. Such infringements also may cause interruptions of administrative sector services and 


\section{The International Journal \\ ENTREPRENEURSHIP AND SUSTAINABILITY ISSUES}

ISSN 2345-0282 (online) http://jssidoi.org/jesi/

2016 Volume 4 Number 1 (September)

definitely create an atmosphere suitable for corruption (Tvaronavičienè, Grybaitė, 2012; Fazekas et al. 2013; Hessami 2014). Fulfilling public procurement requirements in regard of acquisition of necessary goods and services is a duty of almost every public administration body as well as other organizations. Having in mind high number of such entities, it should be stated that authorised institutions are not able to detect all the infringements. Statistics shows, that for example in Lithuania, only small part of procurement procedures are supervised by competent authorities (Special Investigation Service of the Respublic of Lithuania 2014; Ministry of the Interior of the Republic of Lithuania 2014; Public Procurement office 2014). That is why, the main role in the battle with not honest behaviour of purchasing authorities should be envisaged for suppliers, whose rights and interest may be damaged. Seeking to defend their rights, they normally initiate legal procedures, aimed to investigate whether certain decisions of purchasing authorities do not contradict requirements setted down in legal regulation. The effectiveness of such control mechanism is strongly dependent from the clearness, transparency and simpliness of public procurement disputes resolution procedure.

It should be stated that today in Lithuania there is quit low number of public procurement disputes. The quantitative research conducted in Lithuania (Tvaronavičienè 2015) revealed that comparatively few public procurement disputes are resolved in courts. Claims in respect of which judicial decisions are taken, in most cases are rejected, and interim measures are relatively rarely applied. Such data shows that today in Lithuania tenderers contribute little to the assurance of procurement legality.

In Lithuania, the application of exclusively judicial review procedure for the decisions of the purchasing authorities faces several issues. Resesarcher discovered too long dispute resolution, declarative and not functional system of unmeritorious claims provision preventive measures, the absence of specialisation of judges, the uneven judicial practice, failure to use specialised electronic procurement system for a dispute resolution process, low confidence in courts, complex and formal dispute resolution process and insufficiently effective pre-litigation procurement dispute resolution stage. All these problems imply the need to search for the opportunities to improve dispute resolution system of public procurement.

\section{Adopting Social Technologies for More Effective Public Procurement Dispute Resolution}

No areas of contemporary life, including state governance, today can function well without social technologies. E-governance may be described as a phenomenon governed by state and municipal bodies aimed at development of society relations. Its goal is to improve the transparency of executive bodies' decisions, to provide better quality and more effective public services and information for society, business entities and institutions, using opportunities provided by information technologies (Ereminaitė Junevičius 2011). It should be stated that using social technologies in public sector leaves less space for corruption, improves transparency, strengthen reliance on government and decreases costs of public institutions. It is possible to list four principles of e-governance: creation of services for citizens, increasing the accessibility of public services, better involvement of various social groups as well as more effective collection and employment of information (Ereminaitė\&unevičius 2011). It is clear that at present public procurement dispute resolution systems may and should be improved by searching possibilities to employ as much as possible social technologies.

Electronic procurement in Lithuania was started to use in year 2008. Currently in Lithuania public procurement eprocedures may be carried on via Central Public Procurement Information System. From the year 2009, all purchasing authorities in Lithuania were obliged to ensure the acquisitions of goods, services and works online every year would consists no less than 50 percent of the value of all fulfilled procurements (Law on Public Procurement 1996). Such formal requirement fated that e-procurement became very popular and in the year 2011 more than 75 percent of all advertised public procurements were carried online. In the year 2013 the number of eprocurements have already reached 87 percent (Public Procurement Office 2014). It should be stated that in regard of number of e-procurement Lithuania is one of the leading countries in EU. 


\section{The International Journal \\ ENTREPRENEURSHIP AND SUSTAINABILITY ISSUES}

ISSN 2345-0282 (online) http://jssidoi.org/jesi/

2016 Volume 4 Number 1 (September)

In the report of Electronic public procurements (Public Procurement Office 2014), which was presented by Office of Public Procurement, was noted that CVP IS have changed the attitude of participants towards public procurement procedures, because it provided better guarantees for transparency, confidentiality, equality and accessibility of procedures. E-procurements became a measure, which successfully worked to save money, human resources and time for suppliers and purchasing authorities. As well as information about advertised procurements became available for all internet user (Public Procurement Office 2014). In EU strategies, it is planned to widen usage of electronic means in public procurement. For example, on the 26th of June 2013, European Commision established $\operatorname{COM}(2013)$, in which it was stated that, , $<\ldots>$ The transition to end-to-end e-procurement can generate significant savings, facilitate structural re-thinking of certain areas of public administration, and constitutes a growth enabler by opening up the Internal Market and by fostering innovation and simplification. It can also facilitate SME participation in public procurement by reducing administrative burden, by increasing transparency over business opportunities, and by lowering participation costs "(European Parliament 2013). In Lithuania such goals are already reached. It encourages going forward.

It is necessary to draw attention towards a possibility to apply online tools in public procurement. It should be stated that despite of a fact that online dispute resolution was not mentioned in COM (2013), still indirectly it was stated that fully electronic procurements would shorten the procedure and decrease the litigation cases. „End-toend e-procurement can improve the overall administrative efficiency by cutting the duration of the purchase-topay cycle, by reducing administrative burden, and by improving auditability. These in turn, reduce the opportunity for corruption and tax fraud, increase security of data and reduce litigation"(European Parliament 2013). Contemporary concept of fully electronical procurements covers e-notification, e-access to procurement documents, and e-submission phases. Novelty in this field - e - invoicing. European Commision predicts that einvoicing in public procurement all over the EU would let to save about 2,3 mlrd. Euro (eu2013.lt 2013). In Lithuania after the implementation of project "Electronical services "E-invoice", which was started in the beginning of 2015, e-invoices of public procurement contracts will fully change the paper invoices. It will allow not only to save paper and time, but also will provide an tool for authorized institution to control the implementation of public procurement contracts (Ministry of Finance 2014).

The next step for full electronical procurement definitely can be e-review of public procurement. It is obvious that development of technologies can help to cope easily with documentations and to reduce time and cost necessary for resolution of high number of similar disputes (Gill et al. 2014). On the same time it would create accessibility of the procedure and interested person would be able to assess procedure whenever he needs and from where ever he is.

According Philipe, ODR (abbrv. for online dipute resolution) platforms consist of electronical communication tools, usefull in generation, sending, receiving, storing, sharing of information (Gill et al. 2014). This scientist notes that, effective ODR tool should be designed taking in consideration goals to automate basic functions of case management as registering of cases, confirmations, reminders and fixing of results. Well-designed ODR platform can increase the transparency of dispute resolution procedure and promote the usage of it, because parties to a dispute will rely more on it (Gill et al. 2014). These insights shows, that public procurement review system needs such characteristics in order to make his procedure more transparent and respectable.

EU legislation have already established requirements for online consumer disputes resolution (Gill et al. 2014). It was planned to implement unified system for non-judicial consumer dispute resolution till the 1st of January 2016. In most countries such platforms, which join all national bodies and are available for consumers in all EU languages are already operating. Such initiative shows that virtual resolution or review of dispute is a near future reality and after few years, it will become usual procedure for peoples who enters contracts online. 


\section{The International Journal \\ ENTREPRENEURSHIP AND SUSTAINABILITY ISSUES}

ISSN 2345-0282 (online) http://jssidoi.org/jesi/ 2016 Volume 4 Number 1 (September)

After the analyses of scientific literature in the field of public procurement, it should be stated that public procurement review system is separated from public procurement procedure. These two systems are always investigated separately. The same distinction can be noticed in case of e-procurement. E-procurement system is designated for carrying on a procurement procedure, but do not deal with resolution of disputes in this area. Thus such separation, do not create possibilities to integrate these two important parts of the same process. Such integration may be easily made online. Having in mind that for example in Lithuania e-procurements was easily adopted by contracting authorities and suppliers, it may serve as a sign that these entities are able not only to enter the legal relation online, but also to resolve their disputes online.

E-review should also be very usefull for supervising bodies and scientists to monitor the process of dispute resolution. According Kristina Detelj et al (2015), there are big differences between the member states even when collecting the data aboutprocurements above the threshold, and let alone when reporting procurements below thethreshold. These differences as well are notable, when we discuss the issue of public procurement review systems. Digital content is always more easy to analyse. Contemportary information technologies would help to get comprehensive statistical data, which would be usefull for identifiying problems. Such statistical is also necessary for science. Cuurrently in the field of public procurement within EU it is impossible to get reliablke statistical data for more presize that overviewing scientific researces.

Concluding it should be stated that in order to secure effective public procurement review procedure it is necessary to search for technological solutions for integration of e-procurement system with new module for e-review of contracting authorities decisions. Such solution might enable supliers to claim easily for review by electronic means, allow reviewing bodies to get acquainted with all procurement documentation directly in online system and encourage to perform all review procedure online, what definitely would allow to save time, money and secure transparency.

\section{Assesment of the Current Public Procurement Dispute Resolution Procedure}

To identify practical problems of currently applied system of public procurement and investigate the possibilities for online public procurement review procedure, qualitative approach was chosen and expert assessment method was selected (Vainauskienė et al. 2016). The questionnaire was provided to three groups of experts, meeting criterias of (1) field of work related to public procurement (representatives of purchasing authority, judiciary (advocates, judges) and representatives of controlling institution) - totally 18 experts (2) with experience in this field not less than 4 years and (3) working with public procurements not less than four times per year.

Expert survey was conducted in February - March 2016. Expert survey was conducted in online mode. Experts were selected using snowball sampling. The research was completed, when the experts suitable for the needs to deliver all of the above groups opinion were found. The least presented is judiciary expert group as totally were invited 11 experts, but only 4 of them completed the survey. Analysis of the results completed in the context of public procurement review procedures' effectiveness. This paper presents only a part of survey results. The qualitative content analysis method was applied for open opinions. For evaluation questions, quazi quantification was applied. Expert opinions compatibility was tested for responses to each question, calculating the Kendall's concordance coefficient $\mathrm{W}$. Considered, that the appropriate expert compatibility is where $\mathrm{W} \geq 0.5$.

The concordance rate indicates that there are differences of opinion between experts $(\mathrm{W}=0,393)$. Therefore the relation of the expert assesments of different questions was analysed (Kendall's tau b correlation coefficient calculated). The coefficient calculation shows that the treatment of different questions is independent of the experts' experience, while Kendall concordance coefficient indicates that there is a better coincidence of opinions in the following expert groups: experience up to 10 years $(\mathrm{W}=0.447)$ and experience of 10 years and more $(\mathrm{W}=$ $0,422)$. 


\section{The International Journal
TAINABILITY ISSUES}

ISSN 2345-0282 (online) http://jssidoi.org/jesi/

2016 Volume 4 Number 1 (September)

Problems were evaluated in 10 point system, where 1 - very bad, 10 - great. Importance of the problems calculated based on expert evaluation averages (see Table 1). The table shows the valuation averages, calculated from all the expert opinions. To adjust average grades, the outliers eliminated.

Standardized values can be used to formally define outliers. The monitoring of Vari-line the standardized value of $\mathrm{z}$ of which is between 2 and 3 is considered notionally outlier.

The standardized value is calculated according to the formula:

$$
z=\frac{x-\bar{x}}{s}
$$

where $\mathrm{z}$ is standardized value, $\mathrm{x}$ stands for instantaneous value of variable, $-\mathrm{x}$ is average variable, and $\mathrm{s}$ stands for the standard deviation.

In Table 1 presented calculations of adjusted evaluations averages. Note that averages have changed slightly, the order of their importance remained almost unchanged. After summarizing the expert assessments, it must be concluded that the existing procurement review system is a little more than average in line with their needs. Experts'assessments do not reflect public procurement dispute resolution issues being escalated in the society, because they basically assess the existing system positively. Taking into account that, according to the opinijon of the most of the experts, the system is not worth the highest grade, it is necessary to look more deeply and search for the reasons of the extperts 'dissatisfaction with the existing system. For the detailed evaluation averages see Table 1. Experts some more than averagely (assessment rate more than 6 but less than 7) assess mandatory prejudicial claim procedure. Many of them motivate the relatively low rating by the argument that the claiming procedure does not defend effectively damaged rights and legitimate interests of suppliers (ratings up to 6) as well as in many cases does not prevent suppliers from abuse of the right for justice. The experts partially agreed with the statement that claiming procedure is ineffective due to blocking the procurement procedure (rating as much as 4.06). At first glance, they also partially agreed with the statement that claim procedure is ineffective, because the subject, which it has adopted the decision under dispute, examines the claim. However, the appraisal by experts in procurement procedures, revealed that the suppliers and controlling institutions support this assertion. This is natural, as the contracting authorities, being interested in preservation of their jurisdiction to examine the claims are susceptible to this pre-dispute claim settlement procedure stays unchanged.

Suppliers' interests are protected less than the interests of the contracting authorities. Experts recognize that a large number of manifestly unfounded claims significantly reduces the effectiveness of the procedure, which raises the need for research for further preventive measures. According to the experts, the judges' qualifications and competence in the field of public procurement is not sufficient (rating 6.06). It should be noted that the experts assessed this statement partially differently. It can be seen that advocates are more cautious in the assessment of the competence of judges, while in the opinion of the expert-judge, the qualifications should be assessed as fine. Suppliers and contracting authorities consider this statement similarily. Suppliers' administrative burden in litigation is assessed by experts as an important factor of the dispute settlement system inefficiencies.

Experts were also asked about the impact of litigation-term for the efficiency of judicial dispute resolution procedure. The results show that in the experts' opinion, this is an important indicator that identifies the shortcomings of the existing system. Experts representing contracting authorities and controlling bodies paid special attention to the duration of the procedure concidering it a very important disturbance to the effieciency. 


\section{The International Journal \\ ENTREPRENEURSHIP AND SUSTAINABILITY ISSUES}

ISSN 2345-0282 (online) http://jssidoi.org/jesi/ 2016 Volume 4 Number 1 (September)

Experts agree that the noticed existing deficiencies can be eliminated. Experts confidently agree on the need to establish a specialized pre-juditial body for the review of contracting authorities' decisions (especially judges, lawyers and controlling entity). This confirmed by three additional comments of the experts, which highlight the likely benefit of the establishment of specialized institution. Experts also supports the idea of a need for dispute settlement bodies specialization and agree the dispute resolving bodies to be granted access to the CVPIS (Central Public Procurement Information System) data in the specific purchase under dispute.

Table 1. Experts' evaluation averages. Problems discovered in public procurement review procedure and recommendations to solve them.

\begin{tabular}{|c|c|c|}
\hline Issues & $\begin{array}{l}\text { Average } \\
\text { assessment rate }\end{array}$ & $\begin{array}{c}\text { Adjusted } \\
\text { average } \\
\text { assessment rate } \\
\end{array}$ \\
\hline To what rate would you assess the current public procurement dispute resolution procedure? & 6,50 & 6,56 \\
\hline $\begin{array}{l}\text { To what rate would you assess the current mandatory pre-judicial public procurement claim } \\
\text { procedure? }\end{array}$ & 6,78 & 6,88 \\
\hline \multicolumn{3}{|c|}{ Evaluate the efficiency of the current mandatory pre-judicial public procurement claim procedure } \\
\hline $\begin{array}{l}\text { With the help of claim procedure, purchasing authorities have the possibility to notice } \\
\text { violations of legislation and to eliminate them }\end{array}$ & 7,33 & 7,94 \\
\hline By the claim procedure violated suppliers' interests are protected effectively & 5,89 & 6,20 \\
\hline The claim procedure prevents suppliers abuses to justice & 5,67 & 5,40 \\
\hline The claim procedure is ineffective as it blocks public procurement procedures & 4,33 & 4,06 \\
\hline $\begin{array}{l}\text { The claiming procedure is ineffective as the claim is investigated by the same entity that has } \\
\text { take the decision under dispute }\end{array}$ & 4,67 & 3,60 \\
\hline Claim procedure is ineffective because it restricts suppliers' right to judicial protection & 2,83 & 2,13 \\
\hline How would you rate the current judicial procedure for procurement dispute resolution? & 6,72 & 6,81 \\
\hline \multicolumn{3}{|c|}{ Rate the effectiveness of the current judicial public procurement dispute resolution procedure } \\
\hline $\begin{array}{l}\text { Judicial dispute resolution procedure effectively protects the interests of the affected } \\
\text { contracting authorities }\end{array}$ & 6,61 & 7,19 \\
\hline $\begin{array}{l}\text { Judicial dispute resolution procedure ensures formation of uniform practices in public } \\
\text { procurement }\end{array}$ & 6,22 & 6,81 \\
\hline Judicial procedure for dispute resolution effectively protects violated interests of suppliers & 6,22 & 6,47 \\
\hline $\begin{array}{l}\text { Judicial procedure of dispute resolution is inefficient because considers many manifestly } \\
\text { unfounded claims }\end{array}$ & 5,61 & 6,40 \\
\hline $\begin{array}{l}\text { Judicial dispute resolution procedure guarantees high qualifications and competence in public } \\
\text { procurement of resolving operators }\end{array}$ & 6,06 & 6,06 \\
\hline $\begin{array}{l}\text { Judicial dispute resolution system is inefficient, because makes a disproportionate } \\
\text { administrative burden for the suppliers }\end{array}$ & 4,17 & 3,82 \\
\hline $\begin{array}{l}\text { Judicial dispute resolution system is effective because its duration does not adversely affect the } \\
\text { timely contracting authorities supplying with necessary goods, services and works }\end{array}$ & 4,17 & 3,60 \\
\hline $\begin{array}{l}\text { Judicial dispute resolution procedure is ineffective, as in litigation the supplier has to be } \\
\text { represented by a holder of higher legal education }\end{array}$ & 4,11 & 3,38 \\
\hline \multicolumn{3}{|c|}{ Recommendations for the improvement of the current public procurement dispute resolution procedure } \\
\hline To establish specialized public procurement dispute resolution pre-judicial entity & 8,17 & 9,47 \\
\hline To introduce specialization for the judges in public procurement dispute resolution & 8,67 & 9,25 \\
\hline $\begin{array}{l}\text { To give access to the CVP IS (central public procurements information system) specific } \\
\text { procurement data to resolving subjects }\end{array}$ & 8,11 & 8,53 \\
\hline To set shorter public procurement dispute resolution terms in the law & 6,28 & 6,28 \\
\hline $\begin{array}{l}\text { To improve pre-judicial dispute resolution procedure, with simultaneous obligation to a } \\
\text { purchasing authority to establish a separate commission for the investigation of the claim }\end{array}$ & 4,78 & 3,87 \\
\hline
\end{tabular}

Source: authors.

The examination of the possibilities to improve dispute resolution procedure of public procurement by adapting social technology, found that the experts welcome supplementing of CVP IS by additional dispute resolution function, and see the essential advantages of such a system. For the detailed averages of the evaluation see Table 2. The highest assessment rate was given to the statement that such extension of the CPP IS should ensure that the 
same system carries out all the specific procurement procedure actions. The statements on the possibility of dispute adjudicating entity to access the documentation of the specific procurement within the system as well as the decline in the administrative burden on the parties were also particularly welcomed. Experts gave less importance to the dispute resolution process promptness, transparency and cost-effectiveness. This is related to the fact that the mere extension of the CPP IS by the dispute resolution functionality cannot be a reason to speed, low cost and transparency of the procedure.

Table 2. Experts' evaluation averages. Evaluations on perspectives of applying social technologies in public procurement review process.

\begin{tabular}{|c|c|c|}
\hline Issues & $\begin{array}{l}\text { Average } \\
\text { assessment rate }\end{array}$ & $\begin{array}{c}\text { Adjusted } \\
\text { average } \\
\text { assessment rate }\end{array}$ \\
\hline $\begin{array}{l}\text { How do you assess the possibility of granting a dispute resolving authority with an access to a } \\
\text { particular procurement documents in CVPIS? }\end{array}$ & 8,06 & 8,47 \\
\hline \multicolumn{3}{|c|}{$\begin{array}{l}\text { If the CVP IS is supplemented by an additional dispute resolution function, thus developing a space for filing and resolving claims as } \\
\text { well as applying to specialized public procurement dispute resolution authority, what ADVANTAGES of such system would you see? }\end{array}$} \\
\hline A single system is used for all the specific procurement procedure related actions & 9,11 & 9,38 \\
\hline Dispute resolving entities may have access to all the specific procurement documentation & 8,72 & 9,31 \\
\hline Decreasing administrative burden for suppliers and contracting authorities & 7,83 & 8,38 \\
\hline Accelerating the dispute resolution process & 7,06 & 7,81 \\
\hline The transparency and impartiality of the dispute resolution process & 6,61 & 7,60 \\
\hline Falling financial costs of dispute resolution & 6,50 & 7,19 \\
\hline \multicolumn{3}{|c|}{$\begin{array}{l}\text { If CVP IS is extended to additional dispute resolution functionality, providing an environment for claims submission and examination } \\
\text { as well as the application to a specialized procurement dispute resolution authority, which SHORTCOMINGS would you see? }\end{array}$} \\
\hline financial resources needed to develop and implement the necessary added functionality & 8,11 & 8,88 \\
\hline $\begin{array}{l}\text { Not all procurement specialists will be able to / could quickly learn how to use the information } \\
\text { system }\end{array}$ & 4,44 & 4,12 \\
\hline $\begin{array}{l}\text { For information system availability and simplicity of use possibility for suppliers to abuse their } \\
\text { rights is increasing }\end{array}$ & 4,78 & 3,87 \\
\hline $\begin{array}{l}\text { The creation of such a system is not appropriate for small number of disputes arising from the } \\
\text { legal relationships of procurement }\end{array}$ & 2,89 & 2,53 \\
\hline
\end{tabular}

Source: authors.

However, an attention shall be paid to the fact that the new functionality should be desined in the way that helps implementing the basic public procurement principles. This is approved by additional comments of the experts (see Table 3). The experts emphasize risks related to the safety, such as breach of confidentiality, leaking of information in the benefit of the competitors, if the system is not improved and access limited. Problems in the current legislation and interpretation of the legal norms can be noticed as well. 


\section{The International Journal \\ ENTREPRENEURSHIP AND SUSTAINABILITY ISSUES}

ISSN 2345-0282 (online) http://jssidoi.org/jesi/

2016 Volume 4 Number 1 (September)

Table 3. Content analysis of experts open opinions on public procurement system improvement by social technologies.

\begin{tabular}{|c|c|c|c|}
\hline Theme & Subtheme & Comment & Expert \\
\hline \multirow[t]{3}{*}{$\begin{array}{l}\text { System } \\
\text { improvement by } \\
\text { restricting the } \\
\text { rights ofpreview }\end{array}$} & $\begin{array}{l}\text { Risk of } \\
\text { information } \\
\text { leak }\end{array}$ & $\begin{array}{l}\text { It is appropriate to improve the CPP IS that other suppliers would not be able to } \\
\text { see all the procurement documents. Since there are cases when the public } \\
\text { procurement controlling authority does not analyse contracts uploaded, while the } \\
\text { instrument is more convenient for suppliers: they analyze prices, the market, the } \\
\text { planned further procurement actions. }\end{array}$ & Expert 1 \\
\hline & $\begin{array}{l}\text { Risk of } \\
\text { confidentiality } \\
\text { breach }\end{array}$ & $\begin{array}{l}\text { However, it will be able to see the confidential information, other tenders. Unless } \\
\text { CVPIS functions are modified. }\end{array}$ & Expert 4 \\
\hline & $\begin{array}{l}\text { Risk of } \\
\text { confidentiality } \\
\text { breach }\end{array}$ & $\begin{array}{l}\text { It should make it possible to regulate the type of information available (what } \\
\text { letters, correspondence, etc.) In order to protect confidential information of other } \\
\text { suppliers especially in the case where it is not relevant to resolving a dispute. }\end{array}$ & Expert 11 \\
\hline \multirow{2}{*}{$\begin{array}{l}\text { Improve legal } \\
\text { regulation and } \\
\text { interpretation }\end{array}$} & Legal risks & The problem is unclear legislation, their different interpretation and explanation. & Expert 4 \\
\hline & $\begin{array}{l}\text { Functional and } \\
\text { legal risks }\end{array}$ & $\begin{array}{l}\text { Consideration should be given to ensuring the protection of confidential } \\
\text { information functionally and legally. }\end{array}$ & Expert 9 \\
\hline
\end{tabular}

Source: authors.

Deeper study showed that experts who evaluated the current procurement dispute resolution system quite negatively have higher expectations with respect to its improvement. They believe that the proposed improvement of the system will substantially improve the situation. Eg. those experts who felt that the current claim procedure is of minor efficiency in determining the errors or irregularities committed by contracting authorities, welcome the proposal to allow access to procurement documentation within the CVP IS platform. It should also be noted that those experts who while evaluating the current dispute resolution system had not supported the introduction of specialization of judges, welcome the opportunity to provide disputes resolution operators with the access to the specific contract documents in the CVP IS (see Table 4). It may be assumed that these experts do not see the dispute specificity to the point where the judges would need specialization (this could be linked with relatively small number of court cases originating from the public procurement legal relation). However, these experts are firmly convinced that access to CVP IS of dispute resolution entities is a great opportunity to improve the existing system. This opinion is probably conditioned by the desire to reduce the administrative burden on the parties and the need to carry out procurements and resolve the disputes within the united platform.

The experts were also given questions regarding the potential weaknesses of such functionality expansion. It turned out that the experts consider financial resources needed for the design and installation of such additional functionality the most risky factor. It is important to emphasize that the experts did not see threats on those arguments, which are identified in the scientific literature as a potential threat. Particularly strong disagreement was expressed to the fact that a small number of public procurement disputes shows unviability of such extension. After the deeper analysis of this aspect, the negative relation was identified, which shows that although such cases are few, the necessity of improvement of the system is envisaging (see Table 4). Negative average connection means that the experts admit that assurance of the system unity is much more important than a small number of disputes. These results confirm the insight expressed in the theoretical part that the relatively small number of public procurement cases can be caused by bumpy formal, complex and expensive current dispute resolution system. 
Table 4. Relations identified in Experts' evaluations.

\begin{tabular}{|c|c|}
\hline & $\begin{array}{l}\text { How do you assess the possibility of granting a dispute } \\
\text { resolving operators access to a particular procurement } \\
\text { documents in CVP IS? }\end{array}$ \\
\hline $\begin{array}{l}\text { Recommendations for the improvement of the current procurement dispute } \\
\text { resolution procedure [to provide access to CVP IS (Central Public } \\
\text { Procurement Information System) data in a specific purchase to review } \\
\text { bodies] }\end{array}$ & $\mathrm{r}_{\tau}=0,627, \mathrm{p}$-level $=0,002$ \\
\hline \multirow{2}{*}{$\begin{array}{l}\text { Recommendations for the improvement of the current procurement dispute } \\
\text { resolution procedure [To introduce specialization for the judges for public } \\
\text { procurement cases] }\end{array}$} & $\mathrm{r}_{\tau}=-0,422, \mathrm{p}$-level $=0,02$ \\
\hline & $\begin{array}{l}\text { If the CVP IS is supplemented by an additional dispute } \\
\text { resolution function, thus developing a space for filing } \\
\text { and resolving claims as well as applying to specialized } \\
\text { public procurement dispute resolution authority, what } \\
\text { ADVANTAGES of such system would you see? [A } \\
\text { single system is used for all the specific procurement } \\
\text { procedure related actions] }\end{array}$ \\
\hline $\begin{array}{l}\text { If CVP IS is extended to additional dispute resolution functionality, } \\
\text { providing an environment for claims submission and examination as well } \\
\text { as the application to a specialized procurement dispute resolution } \\
\text { authority, which shortcomings would you see? [The creation of such a } \\
\text { system is not appropriate for smallnumber of disputes arising from the } \\
\text { legal relationships of procurement] }\end{array}$ & $\mathrm{r}_{\tau}=-0,417, \mathrm{p}-\mathrm{level}=0,039$ \\
\hline
\end{tabular}

Source: authors.

The experts also disagree with the statement that public procurement specialists would not be able to use the information system. This approves the information concerning high computer knowledge of public procurement specialists. This fact can be stated based on the range of successful and wide use of electronic public procurement in Lithuania. Neither the experts think that possibilities to abuse the rights due to accessibility and simplicity to use of the information system. The conclusion can be made that in the opposite case, i.e. accessibility and simplicity to use the suppliers will be motivated to pay attention to illegal decisions of purchasing authorities and defend their rights more actively thus making all public procurements in the EU more transparent and ensuring honest competition.

\section{Conclusions}

Summing up the results, and in conjunction with the theoretical part of the paper, it is appropriate to identify that the object of the research is poorly studied. Given the novelty of the subject, it can be concluded that the scientific literature on such a specific object of research is currently not available. The available literature considers only the contexts, e.g. public procurement procedures, including e-procurement, existing different review systems for decisions of contracting authorities, but not an opportunity to carry out such a review by electronic means. Therefore, the investigation was focused to the expansion of knowledge about the subject and trend prediction. This led to a key limitation - it is currently difficult to develop discussion at national or EU level, to summarize the results of different authors and studies.

The results showed that the questions and highlighted problematic aspects raised in the theoretical part are important in expert opinion as well. Although the current national contracting authorities' decisions' review 


\section{ENTREPRENEURSHIP AND SUSTAINABILITY ISSUES \\ The International Journal}

ISSN 2345-0282 (online) http://jssidoi.org/jesi/

2016 Volume 4 Number 1 (September)

procedure was not viewed as negative by the experts; however, they consider it just a little better than average. It shows the materializing of the theoretical insights for the necessity to look for opportunities to improve this procedure. Experts' assessments have not approved public procurement dispute resolution issues escalated by the society, because they basically evaluated the current system positively. Experts had good enough opinions about the current mandatory pre-judicial claim procedure which they consider an important contribution to the contracting authorities to identify the mistakes and violations of the laws and to eliminate them. However, this system has attracted criticism as well because experts believed that it on the one hand was not sufficiently effective in protecting the interests of suppliers, and on the other hand, did not prevent suppliers from abusing their right to justice.

Qualifying the experts' opinion on the current judicial public procurement review procedure applied in Lithuania, it has been mostly criticized for the lack of qualification in the field of public procurement of the judges dealing with such cases. As well as significant administrative burden for suppliers who want to protect their violated rights, and the duration of the litigation which the experts believed was too long. The latter two problems can be solved with social technologies, therefore there is the need for further research, analysis of foreign best practice.

When asked about the development of the review procedure, the experts confidently called for the establishment of a specialized pre-judicial decisions of contracting authorities review body and very much welcomed the opportunity to provide reviewing bodies with an access to the CVP IS, which contains all the specific contract documentation. Also, experts were very positive about additional extension of the CVP IS by preview function. Mostly the experts grounded such a choice on the need for a single system to perform all purchase-related activities, including the review procedure, which in their opinion would contribute to the reduction of administrative burdens. As the most important shortcomings, the experts pointed out the funds necessary for the creation of the additional functionality, additional financial resources. In view of the need for proper functioning of public procurement system, as one of the priority public policies in the EU, it must be concluded that the design and installation costs could be financed from the EU structural funds as the measures to ensure economy, efficiency and transparency of public procurement. It is important to note that the experts confirmed the statement of the theoretical part that more convenient, simpler and more accessible review procedure may encourage suppliers to protect their violated rights and to help the state ensure greater transparency and integrity of all procurement and prevent corruption-related activities. But at the same any improvement of the system raises a number of issues in system integrity, security, legal regulatory, which are to be delt in the very process of improvement.

Evaluating the results of the research it is necessary to pay attention to several limitations, which may have influenced the tresearch result accuracy. Qualitative research, expert evaluation, and the conclusions reached cannot be applied to the whole population. However, this study has identified guidelines for possible future research. It also helped to identify what respondents it is appropriate to choose for the quantitative analysis of the future. It follows that for a wider study of the object of investigation it is necessary to carry out a quantitative survey of suppliers' opinion.

The experts interviewed in this study played different roles and had different experience in public procurement. So it is not surprising that their opinions on certain statements differed radically, which ordered the investigators to adjust the results of the assessments refusing response values to limits. It is important to mention that the data were gathered and handled in national language. No one researcher is English native speaker. The paper had been translated to the English language at the article's finishing stage. This may cause some incorrect understanding of terminology, description or words.

It should also be noted, that the quantitative research has been conducted in one of the EU member states, in Lithuania. Having in mind that different countries apply different dispute resolution procedures that may have 


\section{FNTREPRENEURSHIP AND SUST \\ The International Journal
TAINABILITY ISSUES}

ISSN 2345-0282 (online) http://jssidoi.org/jesi/

2016 Volume 4 Number 1 (September)

different advantages and disadvantages, there exists a possibility that similar research conducted in other countries may reveal essentially different results. The review directives provide the main requirements for the review of purchasing authorities' decisions; however, enough space is left for the national legislator to choose the most appropriate implementing way thereof. It may be concluded that in countries where specialised public procurement resolution authorities successfully operate, experts would more easily share other insights and assessments than in countries where this kind of disputes are resolved by an ordinary or specialized courts.

A very important future research shall be continued in the field of information technologies. It should be oriented towards identification whether specific modules could supplement electronic public procurement platforms used in the EU member states for purchasing authorities' decisions' review according to the requirements of the Review Directive.

\section{References}

Bilkis, L. 2016. The Preliminary Investigation Report; Public Procurement System Review. Available on the Internet: https://www.vkontrole.lt/failas.aspx?id=2475

Čapas, D.; Čapas, R. 2013. Why foreign investor emphasizes that bureaucracy thrivs in Lithuania (I). Available on the Internet: <http://www.verslaspolitika.lt/kodel-uzsienio-investuotojas-akcentuoja-kad-lietuvoje-klesti-biurokratizmas-i/>

Delfi.lt 2008. 7 out of 8 entities do not participate in public procurement. Available on the Internet: <http://www.delfi.lt/verslas/verslas/viesuosiuose-pirkimuose-nedalyvauja-7-is-8-imoniu.d?id=16462892>

Detelj, K. et al. 2015. Measuring Public Procurement for Innovation at Country Level and the Role of ICT Support, JIOS, 39 (1): 21-32.

Directive 2007/66/EC of the European Parliament and of the Council of 11 December 2007 amending Council Directives 89/665/EEC and 92/13/EEC with regard to improving the effectiveness of review procedures concerning the award of public contracts. Available on The Internet: http://eur-lex.europa.eu/LexUriServ/LexUriServ.do?uri=OJ:L:2007:335:0031:0046:en:PDF

Ereminaite, S; Junevičius, A. 2011. E-Government and E-Business Integration Model in Public Procurement, Management of Organizations: Systematic Research, 57:34-49.

European Parliament 2013. Communication From the Commission to the European Parliament, The Council, The European Economic and Social Committee and The Committee of The Regions. End-to-end e-procurement to modernise public administration. COM(2013) (453 final). Available on the Internet: < http://cor.europa.eu/en/activities/stakeholders/Documents/comm453-2013.pdf>

Fazekas, M. et al. 2013. Corruption manual for beginners. Available on The Internet: <http://econ.core.hu/file/download/mtdp/MTDP1339.pdf>

Gill, C. et al. 2014. Models of Alternative Dispute Resolution (ADR). A report for the Legal Ombudsman. Available on the Internet: http://www.legalombudsman.org.uk/downloads/documents/research/Models-Alternative-Dispute-Resolution-Report-141031.pdf

Girūnas, L.; Mackevičius, J. 2014. Evaluation of frauds in public sector, Entrepreneurship and Sustainability Issues 1(3): 143150.http://dx.doi.org/10.9770/jesi.2014.1.3(3)

Hessami, Z. 2014. Political corruption, public procurement, and budget composition: Theory and evidence from OECD countries, European Journal of Political Economy 34:.372-389. DOI: http://dx.doi.org/10.1016/j.ejpoleco.2014.02.005

Kaunasdiena.lt 2013. The Seimas didn't allowed to take away freedom for infringements of procurement procedure. Available on the Internet: 200147\#ixzz3NC0iRQRy> <http://kauno.diena.lt/naujienos/ekonomika/uz-viesuju-pirkimu-tvarkos-pazeidimus-seimas-laisves-atimti-neleido-

Kysiai.lt 2009. Lithuanian businessmen think that the situation does not change in public procurement. Available on the Internet: <http://www.kysiai.lt/lietuvos-verslininkai-mano-kad-situacija-viesuosiuose-pirkimuose-nesikeicia.html> 


\section{ENTREPRENEURSHIP AND SUSTA \\ The International Journal}

ISSN 2345-0282 (online) http://jssidoi.org/jesi/ 2016 Volume 4 Number 1 (September)

Law on Public Procurement 1996. Oficial Journal, No.84-2000.

Lithuanian Presidency of the Council of the European Union 2013. E-invoicing in public procurement: another step towards end-to-end eprocurement. Available on the Internet: <http://www.eu2013.1t/en/news/features/e-invoicing-in-public-procurement-another-step-towardsend-to-end-e-procurement>

Maga.lt 2008. Bureaucracy and corruption preclude public procurement. Available on the Internet: 〈 http://maga.lt/84084>

Ministry of Finance, 2014. Electronic documentation will change paper ones. Available on the Internet: <http://www.finmin.lt/web/finmin/naujienos?erp_item=naujiena_002465>

Ministry of the Interior of the Republic of Lithuania 2014. Report of Ministry of the Interior of the Republic of Lithuania of 2013. Available on The Internet: http://www.fntt.lt/uploads/docs/2013_VRM_ATASKAITA.pdf

Oganisjana, K.; Surikova, S.; Laizāns, T. 2015. Factors influencing social innovation processes in Latvia: qualitative research perspective, Entrepreneurship and Sustainability Issues 3(2): 186-197.http://dx.doi.org/10.9770/jesi.2015.3.2(6)

Pachnou, D. 2003. Effectiveness of Bidder Remedies for Enforcing the EC Public Procurement Rules: A Case Study of the Public Works Sector in the United Kingdom and Greece. Nottingham: University of Nottingham press.

Public Procurement Office 2011. PPO: Public procurement needs professional specialists. Available on the Internet: 〈https://vpt.lrv.lt/lt/naujienos/vpt-viesiesiems-pirkimams-reikia-profesionaliu-specialistu>

Public Procurement office 2014. Report of Public Procurement office of 2013. Available on The Internet: <www.vpt.lt/vpt/uploaded/2013/.../VEIKLOS_ATASKAITA_FIN_2013.pdf>

Public Procurement Office 2014. Report on electronic public procurement, 2013. Available on the Internet: <https://vpt.lrv.lt/uploads/vpt/documents/files/LT_versija/Administracine_informacija/Ketvirtines_ir_metines_ataskaitos/Metines_veiklos _ataskaitos/2013m/Pazangos_araskaita_EPP2013.pdf>

Special Investigation Service of the Respublic of Lithuania 2014. Report of Special Investigation Service of the Respublic of Lithuania of 2013. Availanble on the Internet: 〈http://www.stt.lt/lt/menu/stt-veikla/veiklos-rezultatai/>

Thai, K., V. 2001. Public procurement re-examined, Journal of Public Procurement, 1(1):9-50.

Tvaronavičienè, A. 2014. A. Pre-litigation dispute resolution procedures in public procurement within European Union. Batumi International Conference on Law \& Politics. Conference proceedings. Batumi: Institute for Academic Development.

Tvaronavičienè, A. 2015. The Peculiarities and Effectiveness of Public Procurement Dispute Respolution System. Vilnius: Mykolas Romeris University.

Tvaronavičienè, M.; Grybaite, V. 2012. Sustainable development and performance of institutions: approaches towards measurement, Journal of Security and Sustainability Issues 1(3): 167-175.http://dx.doi.org/10.9770/jssi/2012.1.3(2)

Vainauskienè, V. et al. 2016. Intuitive scenario development methods. Presented at 21 st international scientific conference, Economics and Management 2016 (ICEM-2016), Brno, Czech Republic.

Vz.lt 2014. Public procurement: where an infringement takes place there must be a responsibility. Available on the Internet: <http://vz.lt/?PublicationId=22e000fe-2d97-4ca5-ba60-b490f0b10404\#ixzz3NC0Ff2de> 


\section{ENTREPRENEURSHIP AND SUSTAINABILITY ISSUES \\ The International Journal}

ISSN 2345-0282 (online) http://jssidoi.org/jesi/

2016 Volume 4 Number 1 (September)

Agnè TVARONAVIČIENĖ is the Associate professor at Faculty of Law (Mykolas Romeris University, Lithuania) and director of Public Law Institute. Research interests: public procurement, dispute resolution, social technologies.

Gintaré ŽÉMAITAITIENE் is the Associate professor at Business and Media School (Mykolas Romeris University, Lithuania) and director of Social Technologies laboratory (Mykolas Romeris University, Lithuania). Research interests: social technologies, innovation diffussion theories.

Tatjana BILEVIČIENE் is the Professor at Business and Media School (Mykolas Romeris University, Lithuania). Research interests: Mathematics (statistics), IT, management and administration, knowledge management, sustainable development, quality of life, business and employment.

Copyright (C) 2016 by author(s) and VsI Entrepreneurship and Sustainability Center

This work is licensed under the Creative Commons Attribution International License (CC BY).

http://creativecommons.org/licenses/by/4.0/

(c) (i) Open Access 